\title{
LOCATION OF VACILLANS IN LINKAGE GROUP VIII OF THE HOUSE MOUSE
}

\author{
J. L. SIRLIN \\ Institute of Animal Genetics, University of Edinburgh, Scotland
}

Received 27.ix.56

VAcILLANs is a recessive gene in linkage group VIII that causes a complex syndrome involving muscular co-ordination, behaviour and reflexes, as well as some metabolic abnormality (Sirlin, r 956).

The position of vacillans relative to two other genes in the same linkage group, brown and misty, has now been analysed. Females heterozygous for the three markers, in coupling, were backcrossed to triple recessive males, on a non-agouti (aa) background.

TABLE I

Progeny from matings $\frac{v c b m}{+++} q \times \frac{v c b m}{v c b m} \sigma$

\begin{tabular}{|c|c|c|c|c|c|c|c|c|}
\hline$v c b m$ & +++ & $v c b+$ & $++m$ & $v c++$ & $+b m$ & $v c+m$ & $+b+$ & Total \\
\hline $4^{2}$ & 118 & 5 & 9 & 9 & 12 & 0 & 0 & 195 \\
\hline
\end{tabular}

The results of the matings are shown in table $\mathrm{I}$. It will be seen that the single-factor segregations are faulty. This, which is due to a mortality in the $v c b \mathrm{~m}$ progeny to be discussed later on, does not interfere with the interpretation that follows. The missing $v c+m$ and $+b+$ progenies make it clear that these are the genotypes that would originate from double cross-overs (there was a single doubtful $v c+m$ animal that, on the weight of the evidence available, has been tabulated as $++m$ ). Therefore, the order of the three genes must be $v c-b-m$.

The female recombination values are : $v c-b, 10 \cdot 8 \pm 2 \cdot 2$ per cent.; $b-m, 7 \cdot 2 \pm 1 \cdot 9$ per cent.; $v c-m, 18 \cdot 0 \pm 2 \cdot 7$ per cent. These values are increased by the depletion in the $v c b m$ progeny (see below) representing one parental class of gametes, but, in spite of that, none of them differs significantly from previously reported ones : $v c-b, 5 \cdot 5 \pm \mathrm{r} \cdot 9$ per cent. (Sirlin, 1956$) ; b-m, 7 \cdot I \pm I \cdot I$ per cent. (calculated by the present author from Woolley, I945); or from their summation: $v c-m, \mathrm{i} 2 \cdot 6 \pm 2 \cdot 2$ per cent.

Table 2 gives the number of brown mice, scored at birth by the colour of the eye, which died before misty and vacillans were recognisable. In view of the close linkage between these three genes it seems fair to assume that most of the dead browns were, in fact, also misty and vacillans. Inclusion of the dead mice, with this assumption, gives 
I 88 presumed $v c b m$ and 132 presumed +++ , which substantially improves the single-factor segregations in table $\mathrm{I}$.

Most probably the greater mortality of browns reflects the simultaneous occurrence of vacillans in a rather unfavourable maternal environment. In the phenotypes dealt with here any mortality is expected to be due to vacillans, rather than to brown or misty, on account of its constitutional weakness. On this assumption, the data seem to show a dependence of the viability of vacillans on parity. In table 2 the ratio of dead browns (probable vacillans) to dead blacks is twice as large in first litters as it is in succeeding litters. This was

TABLE 2

Mortality of brown before age of classification for misty and vacillans

\begin{tabular}{|c|c|c|c|c|c|}
\hline \multicolumn{2}{|c|}{$\begin{array}{c}\text { Order and quantity of } \\
\text { litters }\end{array}$} & $\begin{array}{c}\text { Brown } \\
30\end{array}$ & $\begin{array}{c}\text { Black } \\
4\end{array}$ & $\begin{array}{c}\text { Unclassified } \\
9\end{array}$ & $\begin{array}{c}\text { Total } \\
43\end{array}$ \\
\hline $\begin{array}{l}\text { First (10) } \\
\text { Second (14) } \\
\text { Third (7) } \\
\text { Fourth (1) }\end{array}$ & $\begin{array}{l}\dot{.} \\
\dot{.} \\
\dot{.}\end{array}$ & $\begin{array}{r}30 \\
18 \\
16 \\
2\end{array}$ & $\begin{array}{r}4 \\
6 \\
4 \\
\ldots\end{array}$ & $\begin{array}{l}9 \\
2 \\
\text { I } \\
\text { I }\end{array}$ & $\begin{array}{r}43 \\
26 \\
21 \\
3\end{array}$ \\
\hline & & 66 & 14 & 13 & 93 \\
\hline
\end{tabular}

not apparent in larger previous data (Sirlin, I956), and the discrepancy may be a real one based on the different genetical backgrounds.

Misty and brown are located in division 78 and in the distal end of division 79, respectively, of chromosome i 8 in Slizynski's pachytene map (Slizynski, I957). Therefore, vacillans should be somewhere in division 8o. There is now cytogenetical evidence that the centromere in this chromosome is comprised within divisions 78 to 83 of Slizynski's map (Ford, Carter and Hamerton, I956).

Acknowledgment.-A major part of the work was carried out under a British Council scholarship, which the author gratefully acknowledges.

\section{REFERENCES}

FORD, C. E., CARTER, T. C., AND HAMERTON, J. L. 1956. Cytogenetics of a mouse translocation. Heredity, 10,284 (abstr.).

SIRLIN, J. L. 1956. Vacillans, a neurological mutant in the house mouse linked with brown. F. Genet., 54, 42-48.

SLIZYNSKI, в. м. 1957. Cytological analysis of translocations in the mouse. $\mathcal{F}$. Genet., 55, I22-130.

woolley, G. W. 1945. Misty dilution in the mouse. F. Hered., 36, 269-270. 